\title{
Articles
}

\section{Judicial Self Government in the Netherlands: Demarcating Autonomy}

\author{
By Elaine Mak*
}

\begin{abstract}
Based on which values and to what extent does a specific legal system endorse a model of self-government of the judiciary? How is such self-government shaped? Which lessons can be drawn from practical experiences relating to major organizational reforms? This article addresses these questions with the aim of analyzing the influence of reforms of judicial self-government in the Netherlands on the realization of the core values of independence, accountability, legitimacy, transparency of, and public confidence in the judiciary. Furthermore, this article assesses the influence of reforms of judicial self-government on the separation of powers and democracy as organizing principles for the Dutch legal system. The main focus of the article is on the interaction between rule-of-law values and New Public Management (NPM) values for judicial organization, taking into account the meaning and weight of these values over time in the evolving Dutch legal system. Furthermore, the analysis addresses both the legal framework for judicial government and tensions that have occurred between key actors, in particular judges and the Council for the Judiciary, in their experiences with this legal framework in practice. A red thread which runs through this analysis concerns the demarcation of spheres of autonomy for the different actors in the judicial system. The analysis of organizational reforms clarifies that a dynamic interaction has developed between judges, the bodies for judicial selfgovernment in the Dutch system and the Minister of Justice and Security, revolving around claims of autonomy. The evolved framework of rule-of-law and NPM values for the judicial organization provides a theoretical "lens" for understanding this interaction and its outcomes.
\end{abstract}

\footnotetext{
* Professor of Jurisprudence at Utrecht University (The Netherlands). Contact: e.mak@uu.nl. Thanks to Dr. David Kosar and the JUSTIN team at Masaryk University (Brno, Czech Republic), other participants in the JUDI-ARCH workshop in Prague in October 2017, and Prof. Frans van Dijk (Utrecht University / Dutch Council for the Judiciary) for their comments on previous versions of this article. The research leading to this article has received funding from the European Research Council (ERC) under the European Union's Horizon 2020 research and innovation programme (grant no. 678375- JUDI-ARCH-ERC-2015-STG).
} 
The architecture of the Dutch judicial organization, which encompasses the courts and the judges and staff members working in these courts, has been changed in a profound manner in the last three decades. From its beginnings in the French period (1795-1813) until the 1990s, the judicial organization had been an edifice of autonomous units connected in a "flat" organizational structure at the service of the independent and impartial administration of justice. Judges had a high degree of autonomy in organizing their work and a director for court support at each court, acting on behalf of the Ministry of Justice, dealt with budgetary issues. This traditional structure came to be questioned with the rise of governance based on theories of New Public Management (NPM) in the 1990s, which advocated a more "business-like" approach to the functioning of public institutions and introduced new organizational values for realizing this approach: effectiveness, efficiency, and a client-oriented system. ${ }^{1}$ Simultaneously, calls had increased for the "organizational emancipation" of the judiciary in the balance of powers, in the sense of a transfer of governing and budgetary competences from the Ministry of Justice to the judiciary. ${ }^{2}$ Such a transfer of competences would fit with the evolved conception of separation of powers in the Dutch system. Indeed, the traditional role of the executive branch in the governance of the institutions of the state, including the judiciary, did not fit well with the role that the judiciary had developed in the 20th century as an important actor in the development of the law and the review of administrative action. ${ }^{3}$ Under the effects of the NPM theories and the increased call for judicial self-government, the Dutch judicial organization has been remodeled into a more streamlined and hierarchical system based on a balancing of traditional rule-of-law values and new organizational values. In this system, the autonomy of judges and courts in the organizational architecture had to be redefined and new actors, in particular the Council for the Judiciary established in 2002, were challenged to find their place. After the first decade of experience with this system, the reform of the judicial map in 2013 revived tensions that had come to the fore in practice and triggered further debates.

The reforms of the Dutch judicial organization highlight the issue of government of the judiciary and in particular the issue of judicial self-government. Based on which values and to what extent does a specific legal system endorse a model of self-government of the judiciary? How is such self-government shaped? Which lessons can be drawn from practical experiences relating to major organizational reforms? This article will address these questions with the aim of analyzing the influence of reforms of judicial self-

\footnotetext{
${ }^{1}$ E. Mak, The European Judicial Organisation in a New Paradigm: The Influence of Principles of "New Public Management" on the Organisation of the European Courts (2008) 14 EUROPEAN LAW JOURNAL 718 (2008).

${ }^{2}$ Adviescommissie toerusting en organisatie zittende magistratuur (Commissie Leemhuis), Rechtspraak bij de tijd (The Hague 1998), 10.

${ }^{3}$ S.K. Martens \& T.B. ten Kate, Commentaar d.d. 27 oktober 1999 van de President van en de Procureur-Generaal bij de Hoge Raad op de concept-wetsvoorstellen organisatie en bestuur gerechten en Raad voor de Rechtspraak NEDERLANDS JURISTENBLAD 1615 (2000). See infra, A.II.
} 
government in the Netherlands on the realization of the core values of independence, accountability, legitimacy, transparency of, and public confidence in the judiciary. Furthermore, this article will assess the influence of reforms of judicial self-government on the separation of powers and democracy as organizing principles for the Dutch legal system. ${ }^{4}$ The main focus of the article will be on the interaction between rule-of-law values and NPM values for judicial organization, taking into account the meaning and weight of these values over time in the evolving Dutch legal system. Furthermore, the analysis will address both the legal framework for judicial government and tensions that have occurred between key actors, in particular judges and the Council for the Judiciary, in their experiences with this legal framework in practice. A red thread which runs through this analysis concerns the demarcation of spheres of autonomy for the different actors in the judicial system. For judges, this autonomy can be defined as their authority for making decisions on matters within their competence while demonstrating awareness of the demands of the judicial organization and the society and taking responsibility for their decisions. ${ }^{5}$ A similar definition can be used for reflecting on the role and space for maneuvering of governing bodies within the judiciary, such as the Council for the Judiciary and the Management Boards at the courts. The analysis of organizational reforms will clarify that a dynamic interaction has developed between judges, the bodies for judicial self-government in the Dutch system and the Minister of Justice and Security, ${ }^{6}$ revolving around claims of autonomy. The evolved framework of rule-of-law and NPM values for the judicial organization provides a theoretical "lens" for understanding this interaction and its outcomes. $^{7}$

Although the reforms of the Dutch judicial organization have not escaped the attention of legal scholarship, integrated legal and contextual analyses are relatively scarce. Constitutional scholars have primarily focused on the meaning and guarantee of judicial independence in the new institutional constellation in which the Council for the Judiciary has a central position. ${ }^{8}$ Socio-legal studies have addressed aspects of the functioning of the

\footnotetext{
${ }^{4}$ The article's scope corresponds with the questionnaire presented in D. Kosar et al., 'The Rise of Judicial SelfGovernment: Changing the Architecture of Separation of Powers without an Architect. Questionnaire for the Network of Constitutional Experts' (ERC project No. 678375, Masaryk University, 2017). This article was written on the basis of a national report prepared for this ERC project.

${ }^{5}$ Judges' Code (NVVR-rechterscode), para 2.2.

${ }^{6}$ The Ministry of Justice and Security holds its current name since the fall of 2017. Between 2010 and 2017, the name of the Ministry was Ministry of Security and Justice, a name chosen to highlight the transfer of the police to the Ministry's sole sphere of competence. Before 2010, the Ministry was known as the Ministry of Justice. See https://www.parlement.com.

${ }^{7}$ See infra, A.II.

${ }^{8}$ See inter alia P.P.T. Bovend'Eert \& C.A.J.M. Kortmann, RECHTERLIJKE ORGANISATIE, RECHTERS EN RECHTSPRAAK (2013); P.M. van den Eijnden, ONAFHANKELIJKHEID VAN DE RECHTER IN CONSTITUTIONEEL PERSPECTIEF (2011); R. de Lange, Judicial Independence in the Netherlands, in JUDICIAL INDEPENDENCE IN TRANSITION (A. Seibert-Fohr ed. 2012).
} 
judicial system from a more up-close empirical perspective, including investigations of the views and experiences of judges and court officials ${ }^{9}$ and litigants. ${ }^{10}$ Finally, (legal)theoretical scholarship has provided conceptual and normative insights on the interplay of organizational values in the reforms of the judicial system ${ }^{11}$ and the dynamics between key actors with competences for the government of the judiciary. ${ }^{12}$ The analysis in this article aims to integrate insights from the available literature in its own multifaceted reflection on the Dutch reforms, in which attention will be paid to de facto as well as de iure developments. Based on its study of relevant legal sources and academic literature, this analysis will provide an in-depth overview which was not yet available and which will be able to inform a Dutch as well as an international readership on the values and practical challenges relating to judicial (self-)government in a contemporary state organized on the basis of the "rule of law" principle.

The structure of this article focuses on three aspects: shifts in, practical experiences with and constitutional repercussions of autonomy in judicial government. Firstly, the new forms and rationales of judicial self-government in the Netherlands which have emerged in the last three decades will be outlined in more detail (A). Secondly, attention will be given to the influence of changes in judicial self-government on the realization of the core values for the judiciary in institutional interactions and in the judiciary's connection to the society (B). Next, the analysis will address the influence of these reforms on the concretization of the constitutional principles of separation of powers and democracy in the Dutch system (C). In a brief concluding section, the main insights from this analysis will be summarized and a connection will be made with current European debates on judicial self-government, which are relevant to the Dutch judicial system too (D).

\section{A. Forms and Rationales of Judicial Self-Government: Shifting Autonomy}

For a proper understanding of judicial self-government in the Dutch legal system, it is necessary to study the reforms that have been initiated since the 1990s and the motives underlying these reforms. In particular, the year 2002 marked a key moment of change in

\footnotetext{
${ }^{9}$ See inter alia P.M. Langbroek et al., Performance Management of Courts and Judges: Organizational and Professional Learning versus Political Accountabilities, in HANDLE WITH CARE: ASSESSING AND DeSIGNING METHOdS FOR Evaluation AND DeVelopment of the Quality of Justice (F. Contini ed. 2017); N. Holvast, In the SHAdow of the JUdGe (2017).

${ }^{10}$ H.A.M. Grootelaar \& K. van den Bos, How Litigants in Dutch Courtrooms Come to Trust Judges: The Role of Perceived Procedural Justice, Outcome Favorability, and Other Sociolegal Moderators 52 LAW \& SOCIETY REVIEW 234 (2018).

${ }^{11}$ G.Y. NG, QUALITY OF JUdICIAL ORGANIZATION AND CHECKS AND BALANCES (2007); E. Mak, DE RECHTSPRAAK IN BALANS (2007). See also M.A. Loth \& E. Mak, The Judicial Domain in View: Figures, Trends and Perspectives 3(1) UTRECHT LAW REVIEW 75 (2007).

${ }^{12}$ A.F.M. Brenninkmeijer \& H.A.M. Grootelaar, De strijd om de rechterlijke macht 12 RECHTSTREEKS (2016).
} 
the architecture of the Dutch judicial organization, involving the establishment of more self-governing competences and a more hierarchical management structure for the courts (I) and the beginning of efforts to combine classic rule-of-law values with New Public Management values in the organization of the judicial system (II).

\section{Forms of Judicial Self-Government: More Autonomy and More Hierarchy}

The main actors with powers of self-government for the judiciary in the Netherlands are the Council for the Judiciary, the Management Boards of courts, and bodies with specific tasks, for example concerning the selection and the education of judges. ${ }^{13}$ These actors can be classified as bodies for judicial self-government (JSG bodies), being "any expert body (in which a judge or judges sit) that has some powers regarding court administration and/or the career of a judge". ${ }^{14}$ When considering the composition and competences of these bodies, the role of the Ministry of Justice and Security should be addressed as well. The particularities of the Dutch system come to the fore most clearly in a comparison of the system which was implemented in 2002 and the system which existed previously (see Figure 1). For a proper appraisal of the Dutch system of judicial self-government, the following analysis will also address the de facto balance of powers between the examined main actors.

Figure 1: Actors and competences in judicial self-government in the Netherlands

\begin{tabular}{|c|c|c|}
\hline $\begin{array}{l}\text { Time period: } \\
\text { Competence: }\end{array}$ & Before 2002 & Since 2002 \\
\hline $\begin{array}{l}\text { Negotiation of annual } \\
\text { budget for the judiciary }\end{array}$ & $\begin{array}{l}\text { Courts (director for court } \\
\text { support) and Ministry of } \\
\text { Justice and Security }\end{array}$ & $\begin{array}{l}\text { Council for the Judiciary and } \\
\text { Ministry of Justice and } \\
\text { Security }\end{array}$ \\
\hline $\begin{array}{l}\text { Selection and } \\
\text { appointment of judges }\end{array}$ & $\begin{array}{l}\text { National Selection } \\
\text { Committee and Ministry of } \\
\text { Justice and Security }\end{array}$ & $\begin{array}{l}\text { National Selection } \\
\text { Committee and Ministry of } \\
\text { Justice and Security }\end{array}$ \\
\hline $\begin{array}{l}\text { Development of } \\
\text { directions and guidelines }\end{array}$ & $\begin{array}{l}\text { National Consultation } \\
\text { Bodies (LOVs) and Judges' } \\
\text { Association (NVvR) }\end{array}$ & $\begin{array}{l}\text { Council for the Judiciary, } \\
\text { National Consultation } \\
\text { Bodies (LOVs) and Judges' } \\
\text { Association (NVvR) }\end{array}$ \\
\hline Local court management & Judicial assemblies & Management Boards \\
\hline $\begin{array}{l}\text { Education and training of } \\
\text { judges }\end{array}$ & $\begin{array}{l}\text { National Training Center } \\
\text { (SSR) }\end{array}$ & $\begin{array}{l}\text { National Training Center } \\
\text { (SSR) }\end{array}$ \\
\hline
\end{tabular}

\footnotetext{
${ }^{13}$ This analysis does not address the Public Prosecutor's Service, which is organized separately from the judiciary in the Netherlands and resides directly under the Ministry of Justice and Security.

${ }^{14}$ D. Kosar, supra note $4,7$.
} 
The most prominent JSG body in the Netherlands is the Council for the Judiciary (Raad voor de rechtspraak), which started functioning on 1 January 2002. The Council currently has four members in accordance with the applicable law, which states that the Council is composed of at least three and at most five members. In case of a composition of three or four members, two should be judicial officers. In case of five members, three should be judicial officers. ${ }^{15}$ The non-judicial members generally are persons with experience in public governance. ${ }^{16}$ The members of the Council are appointed by Royal Decree on the recommendation of the Minister of Justice and Security from a list of six candidates at most, drawn up by the Minister in agreement with the Council. The recommendation needs to be approved by a committee composed of members from the judiciary. ${ }^{17}$ In contrast with appointment procedures elsewhere in Europe, the judicial members of the Council are not selected solely by their peers. Criticism of judges on the functioning of the Council, which we will discuss in the next section, in part relates to this procedure and the "distance" it is thought to create between judges and the governing bodies for the judiciary. ${ }^{18}$ Membership of the Council for the Judiciary is for a period of six years and can be renewed once for a period of three years. The chairperson of the Council is appointed from among the judicial members, also by Royal Decree and at the recommendation of the Minister of Justice and Security. ${ }^{19}$ In case of a Council composed of four members, such as the one that is currently in place, the chairperson holds a casting vote in order to ensure the predominance of the "judicial voice" in decisions taken. ${ }^{20}$ The current chairperson, Judge Frits Bakker, has held this position since 1 July 2013.

The Council for the Judiciary is in charge of the administration of the ordinary courts of first instance for civil, criminal, and administrative cases (rechtbanken), the courts of appeal (gerechtshoven), and the two specialized highest administrative courts: the Central Appeals Tribunal (Centrale Raad van Beroep) and the Trade and Industry Appeals Tribunal

\footnotetext{
${ }^{15}$ Art. 84(2) and 84(4) Judicial Organization Act (Wet op de rechterlijke organisatie) as revised in 2011. Between 2002 and 2011, the Council had to be composed of five members. Flexibility in the number of members was introduced after the evaluation of the Council's first years of performance, based on a new estimation of the required capacity for fulfilling its tasks. See Kabinetsstandpunt evaluatie Wet organisatie en bestuur gerechten en Wet Raad voor de rechtspraak (Modernisering rechterlijke organisatie) (2007, https://www.rijksoverheid.nl).

${ }^{16}$ Incompatibilities, in particular political functions, are listed in Art. 84(6) Judicial Organization Act.

${ }^{17}$ Art. 85 Judicial Organization Act.

${ }^{18}$ See infra, B.I.1.2.

${ }^{19}$ Art. 84(3) and 84(5) Judicial Organization Act.

${ }^{20}$ Art. 87(3) Judicial Organization Act.
} 
(College van Beroep voor het bedrijfsleven). ${ }^{21}$ Not under the Council's administration are the Supreme Court (Hoge Raad der Nederlanden) and the Administrative Jurisdiction Division of the Council of State (Afdeling bestuursrechtspraak van de Raad van State). ${ }^{22}$ The reason for this is that these two institutions hold special positions in the Dutch constitutional system as the general courts of final appeal. Therefore, special arrangements have been made for their organization. ${ }^{23}$

The Council for the Judiciary is responsible for preparing the budget for the Council and the courts; allocating budgets from the central government budget to the courts; supporting operations at the courts; supervising the implementation of the budget by the courts; supervising the operation at the courts; and nationwide activities relating to the recruitment, selection, appointment, and training of court staff. The support and supervision of the operations at courts require that particular attention is paid to information systems; accommodation and security; quality of administrative and organizational procedures; personnel matters; and other facilities. ${ }^{24}$ In the performance of its tasks, the Council may issue general directions to the Management Boards of the courts in so far as this is necessary for the proper operation of the courts. ${ }^{25}$

Another task of the Council for the Judiciary is the provision of support for activities of the courts aimed at achieving uniform application of the law and promoting legal unity. The Council is also tasked with advising the government and the States General (Lower House and Senate) on generally binding regulations and the policy to be pursued by central government in relation to the administration of justice. Advisory opinions of the Council are adopted after consultation with the courts. ${ }^{26}$ In performing the aforementioned tasks, the Council is bound to a so-called "exception of independence", which means that the Council may not involve itself in the procedural aspects or substantive assessment of or the decision in a specific case. ${ }^{27}$

${ }^{21}$ The Central Appeals Tribunal, located in Utrecht, decides appeals in social security and civil service cases. The Trade and Industry Appeals Tribunal, located in The Hague, decides appeals in the field of social-economic administrative law and appeals for specific laws, such as the Competition Act and the Telecommunications Act.

${ }^{22}$ Art. 2 and 3 Judicial Organization Act.

${ }^{23}$ For the Supreme Court, a covenant outlines the Court's relationship with the Ministry of Justice and Security with regard to the operation of the Court (https://www.rechtspraak.nl). The Administrative Jurisdiction Division is governed as a part of the Council of State, beside the Advisory Division on legislation and governance.

${ }^{24}$ Art. 91 Judicial Organization Act.

${ }^{25}$ Art. 92(1) Judicial Organization Act.

${ }^{26}$ Art. 94 and 95(1) Judicial Organization Act.

${ }^{27}$ Art. 96(1) Judicial Organization Act. 
At every court of first instance and court of appeal, there is a Management Board composed of three members, including a chairperson. ${ }^{28}$ The chairperson has the title of president of the court. This person and one other member of the Management Board are judicial officers. The other member is a court official without judicial tasks. The members of the Management Board at each court are appointed by Royal Decree based on a nomination by the Minister of Justice and Security. Appointment is for a period of six years with a possibility of renewal for a period of three years at the same court. The Minister of Justice and Security bases his nomination on a recommendation provided by the Council for the Judiciary. The Council for the Judiciary has to hear the advice of the court's Management Board, including the view of the works council at the court (i.e. the representative council of employees within the court), before giving its recommendation. ${ }^{29}$

Prior to 2002, the management of each court was in the hands of all judicial officers at a court, forming together the judicial assembly (gerechtsvergadering). This assembly's competences were very limited in practice, as a director for court support (directeur gerechtelijke ondersteuning) affiliated with the Ministry of Justice was in charge of the operation at the court and budgetary issues. ${ }^{30}$ In 2002, a model of "integral" management was introduced, in which judicial officers and directors of operations cooperated. This model reflects the contemporary interpretation of the separation of powers, in which judicial independence encompasses the substantive as well as the organizational position of the judiciary vis-à-vis the other branches of government. ${ }^{31}$ In this model, the Management Board consisted of a chairperson (the president), the chairpersons of the sectors within the court (e.g. the sector for civil cases, the sector for criminal cases, the sector for administrative cases, the sector for small claims (kantonrechter)), and a nonjudicial member (director of operations). ${ }^{32}$ The director of operations is no longer a civil servant at the Ministry of Justice, but has the status of a court official. ${ }^{33}$ The judicial assembly still exists in this new structure, but it only has an advisory competence with regard to the court management. ${ }^{34}$ This governance structure was fine-tuned in 2013, when a reform of the judicial map in the Netherlands took place. From 1 January 2013, the 19 district courts were reorganized into ten and eventually 11 district courts, and the five courts of appeal were reorganized into four courts of appeal. At that time, the internal

\footnotetext{
${ }^{28}$ Art. 15(1)-(3) Judicial Organization Act.

${ }^{29}$ Art. 15(4)-(5) Judicial Organization Act.

${ }^{30}$ Commissie Leemhuis 1998, supra note 2, 22-23.

${ }^{31}$ Ibid., 8-10.

${ }^{32}$ Art. 15 (old) Judicial Organization Act.

${ }^{33}$ Art. 15(2) Judicial Organization Act.

${ }^{34}$ Art. 22(1) and 28 Judicial Organization Act.
} 
organization of courts changed as well: sectors became departments, and the Management Boards were redesigned into smaller and arguably more efficient governing bodies. $^{35}$

The Management Boards at the courts are obliged to establish three types of regulations. ${ }^{36}$ Firstly, each Management Board needs to establish an internal regulation, containing rules about the working methods, decision-making and division of tasks of the board; authorizations to board members to perform specific tasks; and the replacement of board members in case of illness or other obstacles to the performance of their duties. Secondly, each Management Board should establish a governance regulation, which addresses the court's organizational structure; the division of the court into chambers (encompassing one-member and three-member panels); the allocation of cases to the chambers; the way in which the Management Board will perform tasks relating to the operation of the court; and the external contacts of the Management Board. Thirdly, each Management Board will have to establish a regulation for the allocation of cases, setting out for each hearing location in the court's jurisdiction which categories of cases will be dealt with at that location. In establishing this regulation, the Management Board has to take into account the guarantee of access to justice. The three regulations for each court require the confirmation of the Council for the Judiciary. However, the Council can only withhold its confirmation in case of a violation of the public interest, which includes the interest of good access to justice, and the interest of good operations of the court. ${ }^{37}$

Within the framework of the established regulations, the Management Board of a court is charged with the day-to-day management, organization and operations of the court. In particular, the Management Board is responsible for information systems; preparation, adoption and implementation of the budget; accommodation and security; quality of the administrative and organizational procedure of the court; personnel matters; and other facilities. In this context, the Management Board may issue general and specific directions to all officials working at the court. ${ }^{38}$ In performing the aforementioned tasks and in giving directions, the Management Board may not involve itself in the procedural aspects or substantive assessment of or the decision in a specific case or categories of cases. ${ }^{39}$ The Management Board is also tasked with the promotion of legal quality and the uniform

\footnotetext{
${ }^{35}$ Act on the Reform of the Judicial Map (Wet Herziening gerechtelijke kaart), Stb. 2012, 313.

${ }^{36}$ Art. 19(1), 20(1), and 21a(1) Judicial Organization Act.

${ }^{37}$ Art. 21a(2) Judicial Organization Act.

${ }^{38}$ Art. 23(1) and 24(1) Judicial Organization Act.

${ }^{39}$ Art. 23(2) and 24(2) Judicial Organization Act.
} 
application of the law, again within the boundaries set by the "exception of independence". ${ }^{40}$

Several other JSG bodies hold specific competences. An important observation is that the Council for the Judiciary has an influential position in many of these bodies. The National Selection Committee for the Judiciary (Landelijke Selectiecommissie Rechters) is tasked with the selection of new judicial officers and supplementary judges (rechter-/raadsheerplaatsvervanger). ${ }^{41}$ The Committee is composed of 22 members, including a Praesidium of four members, 12 members, and six supplementary members. These members represent the judiciary as well as a variety of societal sectors, including public governance, business, education and science, law firms, and the public prosecutor's service. Members are appointed by the Council for the Judiciary based on a selection made by the Committee itself, taking into account experience with recruitment, selection and/or education of judges and competences such as perception and integrity. ${ }^{42}$ Appointment is for four years for members of the Praesidium. It is for three years for other members and in exceptional cases can be renewed for one year at the advice of the Committee's Praesidium. ${ }^{43}$

New judges are appointed on the basis of a selection procedure which is organized by the National Selection Committee in cooperation with the court where a vacancy exists. The Dutch judiciary currently counts approximately 2.300 judicial officers, who handle around 1.6 million cases per year. ${ }^{44}$ In order to become a judge, candidates need to have the Dutch nationality and they need to have obtained a university degree with effectus civilis, meaning that a certain number of academic legal courses have been completed. Usually, this requires the completion of a bachelor's and a master's degree in law. ${ }^{45}$ Furthermore, candidates will need to have obtained at least two years of relevant work experience outside of the judiciary and be of impeccable behavior, that is: not have received any criminal convictions. ${ }^{46}$ Selected candidates will be appointed after successfully completing

\footnotetext{
${ }^{40}$ Art. 23(3) Judicial Organization Act.

${ }^{41}$ Art. 8(1) Regeling Landelijke selectiecommissie rechters (LSR). A supplementary judge has his or her main occupation elsewhere (e.g. as a university professor) and acts as a judge on a temporary basis (e.g. one day per month) based on the required capacity at the court where the supplementary judge has been appointed.

${ }^{42}$ Art. 2(1)-(4) Regeling LSR. See also https://www.werkenbijderechtspraak.nl//sr.

${ }^{43}$ Art. 5(1) and 5(2) Regeling LSR.

${ }^{44}$ https://www.rechtspraak.nl.

${ }^{45}$ Convenant inzake Civiel Effect (22 March 2016, https://www.advocatenorde.nl). See also De Lange 2012, supra note 8,240 .

${ }^{46}$ Art. 1 Act on the Legal Position of Judicial Officers (Wet rechtspositie rechterlijke ambtenaren).
} 
the education and training program for new judges. The statutory retirement age for judges is 70 years of age. ${ }^{47}$

The Training and Study Center for the Judiciary (SSR) organizes the initial training for judges and public prosecutors as well as courses in the framework of permanent education. ${ }^{48}$ The Center was established in 1960. It engages also in international activities, notably as one of the co-founders of the European Judicial Training Network (EJTN). ${ }^{49}$ Also in judicial training, a concentration of power comes to the fore in the chosen governance structure. The national Training and Study Center is owned by the Council for the Judiciary, ${ }^{50}$ which has shared this ownership with the Public Prosecutor's Service on the basis of a mutual wish to cooperate. A Board of Owners, composed of one representative of each of these two institutions, decides on the substantive and budgetary frameworks for the operations of the Centre. The daily governance of the Centre has been mandated to an Executive Board composed also of representatives of the two involved institutions. The Management Boards at the courts and the National Consultation Bodies (to be discussed next) provide input on the "products and services" to be offered by the Centre. Judges, public prosecutors and academics act as lecturers and trainers in the provided courses. ${ }^{51}$

For the main fields of competence of the ordinary courts, National Consultation Bodies have been established (Landelijk overleg vakinhoud, LOV). These consultation bodies are composed of representatives of all of the courts of first instance and courts of appeal. They develop guidelines for judges, for example on sentencing in criminal cases or alimony in divorce cases. The National Consultation Bodies have played a prominent role also in the development of professional standards for the judiciary in 2016 and $2017 .^{52}$

The Dutch Association for the Judiciary (Nederlandse Vereniging voor Rechtspraak) is the professional organization and trade union for judges and public prosecutors in the Netherlands. It was founded in $1923 .^{53}$ Approximately $70 \%$ of the judges are members of this association. ${ }^{54}$ The general assembly is the central organ of the association. It establishes policies, which are implemented by a board composed of five to seven

\footnotetext{
${ }^{47}$ Art. 117(2) Constitution.

${ }^{48}$ https://www.ssr.nl.

${ }^{49} \mathrm{http}: / /$ www.ejtn.eu.

${ }^{50}$ Art. 40 Decree on the Financing of the Judiciary (Besluit financiering rechtspraak 2005).

${ }^{51}$ http://www.ssr.nl.

${ }^{52}$ https://www.rechtspraak.nl. See also infra, C.II.

${ }^{53}$ http://www.nvvr.org.

${ }^{54}$ https://www.linkedin.com.
} 
members. ${ }^{55}$ A bureau is available to assist members in achieving the optimal performance of their tasks. Special committees prepare advice on topics which are relevant to the association's members, such as advice on law reforms concerning the judiciary, advice on the legal position of judges, and advice on international activities. ${ }^{56}$

In this new landscape of judicial self-government, the most powerful actor de facto is the Council for the Judiciary. ${ }^{57}$ The Council for the Judiciary has obtained a particularly powerful position in the area of court administration, including the budgeting for the courts. Although other bodies are in the lead in the area of judicial appointments and careers, the Council for the Judiciary can exercise power in this area as well, in particular through the appointment of members of the National Selection Committee for the judiciary.

\section{Rationales of Judicial Self-Government: The Rise and Limits of New Public Management}

The most significant change to judicial self-government in the Netherlands has occurred at the beginning of the 21st century. The major reform of the judicial organization at that time, which included the establishment of the Council for the Judiciary and of "integral management" in the courts can be traced back directly to the influence of New Public Management theories on the judicial organization. Further developments based on the same rationality concern the reform of the judicial map and the reform of the Management Boards of the courts, which have taken effect on 1 January $2013 .^{58}$

Core values promoted by theories of New Public Management are: effectiveness, efficiency, and a client-oriented system. ${ }^{59}$ These values were prominent in reforms of the public institutions in the Netherlands towards the end of the last millennium. In this regard, a governmental concern to reduce the costs for upholding the public sector arose in the 1990s alongside increased societal demands of celerity, affordability, and quality of judicial proceedings. ${ }^{60}$ The new design of judicial self-government was intended to cater to these demands. In particular, the Council for the Judiciary and the Management Boards of the courts embody a more "business-like" model, in which small governing units set goals

\footnotetext{
${ }^{55}$ Articles 6 and 7 of the Statutes of the NVvR, available at http://www.nvvr.org.

${ }^{56}$ http://www.nvvr.org.

${ }^{57}$ See infra, B.I.1.2.

${ }^{58}$ See supra, A.I.

${ }^{59}$ Mak, supra note $11,33-36$.

${ }^{60}$ On this trend more generally, see M. Barzelay, Origins of the New Public Management. An International View from Public Administration/Political Science, in NeW Public Management. Current Trends and Future Perspectives (K. McLaughlin, S.P. Osborne \& E. Ferlie eds.2002), 15.
} 
and monitor the performance of the professionals who work in the organization on the basis of these goals. The Agenda for the Judiciary, developed by the Council for the Judiciary every couple of years, demonstrates that policy priorities are set with an eye to improving the realization of values connected with the principle of the rule of law as well as with New Public Management values. ${ }^{61}$ An important current project in the Quality and Innovation Programme (KEI) is a good illustration of the interplay between these values. The digitalization at the courts aims to realize more comprehensible and quicker procedures, inter alia in order to keep a judicial "market share" in the competition with (digital) alternatives for dispute resolution. At the same time, this digitalization serves the guarantee of access to justice, for example by putting aside a possible obstacle relating to a litigant's geographical proximity to a court. ${ }^{62}$

An important base line in this new organizational model is that the core values connected with the principle of the rule of law, in particular the independence and impartiality of the judiciary, should remain safeguarded. This requirement entails that organizational measures aimed at the realization of NPM values are not allowed if these measures endanger the independent and impartial administration of justice. Both types of values come together in a new definition of the "quality" of the judicial system. ${ }^{63}$

From a different angle, the incentive to reform the judicial organization was prompted by shifts in the balance of powers between the three branches of government. This change is visible in particular in the development of administrative judicial review in the Netherlands. As a result of this development, questions arose which touched upon the reconceptualization of rule-of-law values while at the same time acknowledging the demand for the realization of NPM values. The judicial review of administrative action had developed historically in a fragmented manner, resulting in an incoherent and nontransparent system of laws and procedures. As a first step in the reform of this system, the archaic appeal to the Crown-meaning: the government-as a check on judicial review was abolished following two judgments of the European Court of Human Rights (ECtHR), in which the Court established a violation of Article 6 ECHR by the Netherlands. ${ }^{64}$ Furthermore, organizational reforms of the Dutch Council of State were set in motion following the ECtHR's judgments in the case of Procola v. Luxembourg. ${ }^{65}$ At the same time,

\footnotetext{
${ }^{61}$ https://www.rechtspraak.nl.

${ }^{62}$ On the long and not always easy process of innovation, see D. Reiling, 'Court IT: we must, we can, but it's not easy' (blog Technology for Justice, 19 March 2018).

${ }^{63}$ Mak, supra note $1,725$.

${ }^{64}$ Benthem v. the Netherlands, Judgment of 23 October 1985, Appl. No. 8848/80, Series A No. 97; Van den Hurk v. the Netherlands, Judgment of 19 April 1994, Appl. No. 16034/90, Series A No. 288. See De Lange 2012, supra note 8, 231-232.

${ }^{65}$ Procola v. Luxembourg, Judgment of 28 September 1995, Appl. No. 14570/89, Series A No. 326.
} 
a general procedure for administrative judicial review was laid down in the General Administrative Law Act 1994 and administrative sections were established in the courts of first instance with the competence to conduct this judicial review. ${ }^{66}$ These changes affected the reform of the judicial organization, for which a leading motive from the mid1990s onwards was the creation of a coherent and efficient management model for civil, criminal, and administrative judicial decision-making. Still, change has not been realized in some respects. A rejected reform, with effects on the judicial organization, concerned in particular the envisaged integration of appeal in administrative cases into the ordinary court system. ${ }^{67}$ At a more fundamental level, the rise of judicial review of administrative action had an influence on the conception of the judicial role in the balance of powers. Indeed, the traditional idea of a separation of powers, which underpinned the Dutch Constitution of 1815, was less and less reflected in the "checks and balances" that developed in practice between the judiciary and the legislative and executive branches. This change at the macro level of interaction between the three branches of government stimulated calls for increased self-government of the judiciary. ${ }^{68}$

All involved actors in the Dutch reforms seem to have focused their attention on the quality of the justice system rather than on specific interests or claims to power. Therefore, theories which explain the rise of judicial self-government on the basis of power plays, e.g. insurance theory, transnational networks theory, or external incentives theory, ${ }^{69}$ do not seem to be applicable to the Dutch case. An exception might be the debate regarding the realization of more organizational unity in the administrative justice system. In this regard, plans for further reforms have met with severe criticism from the special highest administrative courts. ${ }^{70}$ Although there are good reasons for maintaining the existing system, which operates in a satisfactory manner, the criticism from within the courts could also be interpreted as an attempt to protect vested interests.

\footnotetext{
${ }^{66}$ De Lange, supra note 8, 232 and 234.

67 'Kabinet trekt wetsvoorstel Organisatie hoogste bestuursrechtspraak in' (Dutch government, press release 16 November 2016, https://www.rijksoverheid.nl).

${ }^{68}$ Commissie Leemhuis, supra note 2,8 .

${ }^{69}$ Kosar, supra note 4, 8-9.

${ }^{70}$ W.A.J. van Lierop, Het komen en gaan van het wetsvoorstel Organisatie hoogste bestuursrechtspraak 4, NEDERLANDS JURISTENBLAD (2017).
} 


\section{B. Influence of Judicial Self-Government on the Judiciary's Organizational, Political, and Societal Position: Autonomy in Practice}

The reforms in judicial self-government have had an effect on the internal relations between judges and JSG bodies (I) and on the judiciary's institutional position in relation to the other branches of government (II). Furthermore, the judiciary's interaction with politics and the society has evolved in response to the increased demand for transparency of public institutions (III). As the analysis in this section will clarify, the demarcation of autonomy in judicial self-government has been a central issue in practical experiences with the reformed judicial organization and debates relating to these experiences.

\section{Judicial Self-Government and the Organizational Framework: Independence and Accountability}

A main concern after the reforms of the Dutch judicial organization has been to find an adequate balance between the increased managerialism on the basis of NPM values, expressed in particular in the competences of the Council for the Judiciary and Management Boards of the courts, and the autonomy of judges to reach individual decisions on case management. In this changed context, the space for maneuvering of individual judges needed to be redefined (1). Furthermore, the changes in judicial selfgovernment highlighted a remaining possible weakness in the Dutch constitutional system, which concerns the control by the Minister of Justice and Security of the budget for the judiciary (2).

\section{De lure and De Facto Independence: Redefining the Individual Autonomy of Judges}

The development of the meaning of judicial autonomy in the new model for judicial selfgovernment has given rise to critical analyses and to the codification of professional-ethical guidelines for judges on how to handle the new organizational demands (1.1). Furthermore, the practical experiences with the new organizational framework have led to critical outbursts from judges against the Council for the Judiciary on several occasions, demonstrating an increase of clashes between judicial actors in the new model of selfgovernment (1.2).

\subsection{Tensions in the Legal Framework: How Far Should Organizational Awareness of Judges Go?}

Judicial independence is not explicitly guaranteed in the Dutch Constitution. The Constitution does contain general stipulations, including the appointment of judges for life-that is: until 70 years of age-and the requirement that statutory law will regulate the establishment of courts and the procedures for the suspension and dismissal of judges. ${ }^{71}$

${ }^{71}$ Art. 116 and 117 Constitution. 
An important premise in the Dutch judicial system is that admission to the judicial office is merit-based. Based on this premise, political views or affiliations as well as religion or personal beliefs are not to be considered as criteria in the appointment or promotion of judges. $^{72}$

Article 6 ECHR has been very influential in the Dutch system and the ECtHR's interpretation of "judicial independence" is generally accepted, that is: a definition which involves the test of whether a tribunal meets standards regarding "the manner of appointment of its members and their term of office, the existence of safeguards against outside pressures and the question whether it presents an appearance of independence". ${ }^{73}$

The change of judicial self-government has had an effect on the de iure independence of the Dutch judiciary and its individual judges. A positive aspect was considered to be the strengthening of the position of the judiciary in relation to the executive power through the creation of the Council for the Judiciary. The idea was that the Council would function as a "buffer" between the courts and the executive branch of government, for example by taking care of the annual budget negotiations with the Minister of Justice and Security. ${ }^{74}$

The Judges' Code, a code of conduct for the Dutch judiciary adopted by the Dutch Association for the Judiciary in 2011, provides the following definition of judicial independence:

An independent court system is not a privilege of the magistrate but a fundamental right of citizens in a democratic state governed by the rule of law. ... An independent court system guarantees that the judge's decision is made free from social, economic, or political pressure, and that it is based on the judge's own assessment of the relevant facts and legal foundations in a specific case. ${ }^{75}$ [my translation-EM]

The Judges' Code directs judges to be led by the law and by their own conscience and sense of justice, while taking societal developments and views into account when this is appropriate. The basis for judicial decisions should be the independent assessment of relevant facts and the interpretation of case law and legislation. Judges should be aware that certain cases require professional courage from the judge in order to reach a decision that the judge deems just, even if this decision does not have the broad support of the

\footnotetext{
72 M.F.J.M. de Werd, DE BENOEMING VAN RECHTERS: CONSTITUTIONELE ASPECTEN VAN DE TOEGANG TOT HET RECHTERSAMBT IN NederLAND EN DE AMERIKAANSE DEelstaAt NEW York (1994).

${ }^{73}$ Yakis v. Turkey, Judgment of 25 September 2001, Appl. No. 33368/96. See De Lange, supra note 8, 233.

${ }^{74}$ Kamerstukken II 1999/2000, 27182, no. 3, 11. See also De Lange, supra note 8, 264.

${ }^{75}$ Judges' Code, para. 2.1.
} 
society. ${ }^{76}$ The Judges' Code clarifies that the independent functioning of the judiciary can only be achieved if the constitutional and legal guarantees relating to the position of the judiciary vis-à-vis the parliament and government are respected. For the legislative branch of government, this entails a duty to adopt laws which are reviewable and manageable. Furthermore, the three branches of government should show respect to each other in the fulfillment of their roles. ${ }^{77}$ These guidelines aim to ensure that judges have functional (or substantive) independence, meaning that no other influences than the applicable legal sources can be binding on judicial decision-making in concrete cases. ${ }^{78}$

A problematic aspect for the guarantee of functional independence is that the new hierarchy in court administration has led to perceived constraints on procedural decisions by judges. In particular, the Council has put into place a model containing detailed "production norms", the so-called Lamicie norms. ${ }^{79}$ In this model, cases are classified based on their complexity. Time for handling cases is then allotted on the basis of this classification. The number of cases to be decided is laid down in an annual "production agreement". 80 This model has been perceived as a restriction on the autonomy of judges within the judicial organization. Indeed, the implementation of the model could have as a consequence that judges take procedural decisions based on economic considerations rather than considerations concerning the guarantee of a "fair trial": is it worthwhile to hear extra witnesses in a trial if this would mean that the allotted time for the type of case at hand is exceeded? In this respect, a field of tension has developed between the interest of effective and efficient judicial government and the value of judicial independence. ${ }^{81}$

This tension between judicial government and judicial independence resounds in the Judges' Code. Besides the classic core values of independence, impartiality, professionalism, and integrity, this Code mentions the value of autonomy as a separate core value for judges. The Code defines this value as follows:

Autonomy of the judge on the one hand gives him the necessary freedom in his judicial functioning and on the other hand makes him fully responsible for this functioning.

\footnotetext{
${ }^{76}$ Id.

${ }^{77}$ Id., para. 3.1.

${ }^{78}$ H. Franken, ONAFHANKelIJK EN VerantwoordeliJk (1997), 13. See also R. de Lange \& P.A.M. Mevis, Constitutional Guarantees for the Independence of the Judiciary, in NETHERLANDS REPORTS TO THE SEVENTEENTH INTERNATIONAL CONGRESS OF COMPARATIVE LAW (J.H.M. van Erp \& L.P.W. van Vliet ed. 2006), 327.

${ }^{79}$ P. van der Knaap \& R. van den Broek, Recht van spreken. Een resultaatgericht sturingsmodel voor de rechtsprekende macht 7 BESTUURSKUNDE 313, 319-320 (2000).

${ }^{80}$ De Lange, supra note 8, 236. See further infra, B.I.2.

${ }^{81}$ R. ROBROEK, DE MACHT OVER HET STRAFPROCES (2016).
} 
Autonomy, also sometimes called internal independence, concerns the scope for maneuvering of the judge within his organization. The judge gives shape to his autonomy through his sensible performance and independent capacity for judgment while he forms part of an organization which has to meet demands of efficiency and legality. ${ }^{82}$ [my translation-EM]

\subsection{Clashes in the Judicial Practice: The Council for the Judiciary under Fire}

In practice, the change of judicial self-government in the Netherlands has not led to proven interferences with the independence of the judiciary or individual judges. However, the role taken up by the Council for the Judiciary has been observed with apprehension by a considerable number of judges. A clear sign of concerns about the Council's performance was given with the publication of the so-called Leeuwarden Manifesto in December 2012. This Manifesto was drafted by a number of judges at the Court of Appeal of Leeuwarden. The Manifesto was eventually supported by 700 judges, i.e. one quarter of the total number of judges in the Netherlands. ${ }^{83}$ Newspapers and other media paid attention to the document and to responses from key players in the Dutch judiciary, such as the thenPresident of the Supreme Court, Geert Corstens. ${ }^{84}$ When analyzing the content of the Manifesto and further debates which have ensued about this, the demarcation of autonomy comes to the fore as the central point of concern: autonomy of judges in relation to the Council for the Judiciary and autonomy of the Council in relation to the Ministry of Justice and Security. Although some points of criticism can be considered as fair with an eye to the guarantee of judicial independence, other points of criticism seem to relate more to the process of adjustment to the new organizational architecture.

The Manifesto criticized the performance of the Council for the Judiciary on three points. The Manifesto asked the Council for the Judiciary and the Management Boards of the courts to take measures in order to tackle these concerns. Firstly, the judges supporting the Manifesto did not feel represented by the Council for the Judiciary. They considered that the members of the Council are very far removed from the courts, while the Council operates in a constant dialogue with political actors, in particular with the Minister of Justice and Security. ${ }^{85}$ Related criticism concerned the composition of the Council, which encompasses members who do not perform judicial tasks anymore or have no judicial experience at all, and the very limited involvement of judges in the procedure for selection

\footnotetext{
${ }^{82}$ Judges' Code, para. 2.2.

${ }^{83}$ Leeuwarden Manifesto (Manifest van Leeuwarden). See also M. Fikkers et al., Het Manifest van Leeuwarden: vijf jaar na dato 1024 ARS AEQUI (2017).

${ }^{84} \mathrm{~J}$. Seegers, 'Hoogste rechter van Nederland luidt in brief noodklok over werkdruk' (NRC Handelsblad, 4 February 2013), supporting concerns about the workload of the courts.

${ }^{85}$ Leeuwarden Manifesto.
} 
and appointment of these members. ${ }^{86}$ In a response to this criticism, the Council for the Judiciary has organized meetings at all the courts and implemented regular consultations with courts in order to establish better communication. As a legitimization of its composition, it referred to the intention of the legislator on establishing the Council. ${ }^{87}$ Although this response can be considered adequate, the realization of effective and transparent communication in practice remains a possible weak point. This became clear again, for example, in 2015, when the Council for the Judiciary expressed the intention to close down court locations in less densely populated areas in the Netherlands without consulting judges first. The protests organized by judges, lawyers and citizens who would be affected by this measure led to it being postponed and eventually cancelled. ${ }^{88}$

Secondly, criticism in the Manifesto addressed the temporary appointment procedure for new court presidents, relating to the reform of the judicial map. ${ }^{89}$ According to the judges supporting the Manifesto, this procedure was seriously flawed: in most cases only one candidate was presented to the local advisory committee, giving the Council the power to determine by itself who were going to be the new court presidents. The supporters of the Manifesto feared that the new court presidents, who all met function profiles drafted by the Council for the Judiciary, would be unable to act as a proper counterweight to the Council in issues regarding the administration of the courts. In its response, the Council denied that it had orchestrated the appointment of the new court presidents. ${ }^{90}$ For this point too, adequate lines of communication seemed a main point that needed to be addressed.

Finally, the supporters of the Manifesto claimed that the assessment of judicial performance had come to emphasize output too much. ${ }^{91}$ The judges considered that the more centralized and "business-like" approach to court administration marginalizes the judicial function to a product, which can be managed on the basis of quantified output. In this environment, there is a risk of overrating the statistical performance of judges in individual assessments rather than appreciating the quality of the judicial work, a judge's commitment, and specific personal characteristics. According to the drafters of the Manifesto, the application of the model of "production norms" had resulted in an atmosphere in which cases do not receive the required attention anymore and in which judges make irresponsible choices in order to meet these norms.

\footnotetext{
${ }^{86}$ Ibid. See also supra, A.I.

${ }^{87}$ Council for the Judiciary, 'Brief van de Raad voor de rechtspraak aan iedereen werkzaam in de Rechtspraak over de voorlopige opbrengst van de dialoog tussen Raad en gerechten' (21 February 2013).

${ }^{88}$ E. Jorritsma, 'Toga-protest leidt tot uitstel sluiting rechtbanken' (NRC Handelsblad, 9 September 2015).

${ }^{89}$ Leeuwarden Manifesto.

${ }^{90}$ Council for the Judiciary 2013, supra note 87.

${ }^{91}$ Leeuwarden Manifesto.
} 
Prompted by the Manifesto, the Council for the Judiciary commissioned research on the perceived workload in the courts. ${ }^{92}$ This research confirmed that the perceived workload among judges is high. Identified causes are the high number of cases and the number of extra hours worked in combination with the experienced bureaucratization within the judicial organization, and the loyalty of judges in the sense of wanting to meet the organizational goals set regarding quality and efficiency. ${ }^{93}$ Still, the Council expressed the opinion that the discomfort of the judges supporting the Manifesto had a deeper cause, relating to the increased demands on the judiciary from politics and the society, political and societal criticism of the performance of the courts (e.g. in some instances of erroneous convictions in criminal cases ${ }^{94}$ ), and the scarce public resources which are available for the judiciary. ${ }^{95}$ This debate reveals a tension which is hard to solve, i.e. the aim of realizing a high standard of quality in judicial procedures and their outcomes while being constrained by contextual factors, in particular the available budget and human resources for the courts. It seems to be unavoidable that this tension expresses itself in the dynamics between the courts and the Council for the Judiciary once in a while, as it did previously in debates between the courts and the Ministry of Justice.

Five years after their call for action, in December 2017, the drafters of the Leeuwarden Manifesto considered that the Manifesto and the debate it generated have had positive consequences for the independent position of the judiciary. First of all, the Council for the Judiciary has given firmer shape to its role as a representative body of and for the judiciary, inter alia by giving more attention to the organizational requirements that enable judges to ensure the quality of procedures and judgments. ${ }^{96}$ Moreover, the procedure for the appointment of court presidents has been adapted in order to enhance consultation at the local level of the courts with regard to the recommendation of candidates. ${ }^{97}$ Still, at least one fundamental point of criticism has not been addressed. This concerns the budgeting for the courts.

\footnotetext{
92 B. FRUYTIER ET AL., WERKDRUK BEWEZEN: EINDRAPPORT WERKDRUKONDERZOEK RECHTERLIJE MACHT (2013).

${ }^{93}$ Ibid., 85; M. Husken \& H. Lensink, 'Het grote VN-onderzoek: de rechter geeft zich bloot' (Vrij Nederland, 14 December 2013)

${ }^{94}$ See infra, B.III.1.

${ }^{95}$ Council for the Judiciary 2013, supra note 87.

${ }^{96}$ Fikkers et al., supra note $83,1024$.

${ }^{97}$ Ibid., 1026.
} 


\section{Judicial Self-Government and Judicial Accountability: A Weakness in the Constitutional System?}

An alleged weakness in the current model for judicial self-government remains the dependency of the available budget for the judiciary on developments in the political agenda. $^{98}$ In the past five years, the economic crisis in the Netherlands has led to a decrease of the available total budget for the judiciary. The Minister of Justice and Security has used this decrease as a justification for reassessing the available budget for the judiciary as a part of the Ministry's total budget and taking into account the expected influx of cases and the time used by judges for handling cases. This approach was criticized by the Council for the Judiciary, ${ }^{99}$ the Court of Audit (Algemene Rekenkamer), ${ }^{100}$ and judges from Utrecht and Lelystad (Tegenlicht group) who drafted a "Manifesto 2.0" based on input from one-third of the judges in the Netherlands. ${ }^{101}$ Their concern is that financing based on the available budget will endanger the quality of judicial performance in economic "hard" times and that the judiciary will be reduced to an executive organ of the Ministry of Justice and Security. This concern relates to the perceived constraints on the autonomy of judges because of the incentive to relate procedural decisions to the Lamicie model. ${ }^{102} \mathrm{~A}$ way to loosen the Minister's grip on the finances for the judiciary would be to grant the judiciary the constitutional status of High Council of State, which is a status already held by the First and Second Chambers of Parliament, the Council of State, the Court of Audit, and the National Ombudsman. ${ }^{103}$ Yet, the lower chamber of Parliament in October 2016 rejected a slightly less far-reaching amendment for financing of the judiciary based on a nondepartmental budget plan. ${ }^{104}$ The drafters of the Leeuwarden Manifesto observed in December 2017 that no changes to the status quo appear likely in the near future. ${ }^{105}$ This view was confirmed in early April 2018, when the same amendment after a resubmission again did not get accepted. ${ }^{106}$ It had received public support from the judges of the Tegenlicht group, who claimed: "Ultimately, the judiciary is the sole pillar of the trias

\footnotetext{
${ }^{98}$ Ibid., 1026-1027.

${ }^{99}$ F.C. BAKKER, JAARVERSLAG RECHTSPRAAK 2015 (2015).

${ }^{100}$ COURT OF AUDIT, RAPPORT BEKOSTIGING RECHTSPRAAK: GEVOLGEN VOOR DOELMATIGHEID (2016).

101 'Resultaten enquête Tegenlicht: de rechterlijke organisatie tegen het licht' (https://www.rechtspraak.nl). See also Fikkers et al., supra note 83, 1026-1027.

${ }^{102}$ See supra, B.I.1.

${ }^{103}$ Bakker, supra note 99; Fikkers et al., supra note 83, 1026.

${ }^{104}$ Kamerstukken II, 2016/17, 34426, no. 9.

${ }^{105}$ Fikkers et al., supra note 83, 1027.

${ }^{106}$ Kamerstukken II, 2016/17, 34618, no. 2.
} 
politica which does not have its own budget. This is fundamentally incorrect" [my translation-EM]. ${ }^{107}$

Despite this criticism, arguments in favor of the current institutional arrangement can be found in the "checks and balances" which exist in the Dutch constitutional system. A reason for upholding the current arrangement might be that this arrangement does involve other political actors and in this way provides for a check on the allocation of budget to the judiciary by the Minister of Justice and Security. Based on the applicable laws, the judiciary is financially accountable to the Parliament. The Council for the Judiciary annually establishes a report on behalf of all courts of first instance and courts of appeal, outlining the financial management of the Council and the courts in the preceding budget year and the way in which the work for which the budget was allocated has been carried out. This report is sent to the Minister of Justice and Security, who must forward it to both Chambers of Parliament. An auditor designated by the Council, but whose work can be checked by the Minister of Justice and Security, must give an opinion regarding the accuracy and regularity of the accounts. ${ }^{108}$ Besides this argument of principle relating to the "checks and balances" of the system, it is questionable whether a non-departmental budget would solve the practical problem of perceived pressure among judges to meet "production norms" based on the Lamicie model.

Difficulties relating to the practical implementation of the budget plan come to the fore when we have a closer look at the framework of legal rules and regulations and the de facto experiences with this framework. The Council for the Judiciary supervises the implementation of the annual budget plan by the courts. It also supervises the operation of the courts. ${ }^{109}$ The Decree on the Financing of the Judiciary 2005 specifies that the Minister of Justice and Security makes funding available to the Council for the Judiciary, which the Council then distributes among the courts. In order to fine-tune the budgeting system, the Council measures the "production", "(local) prices", and "workload" in the courts on the basis of the Lamicie model, which categorizes types of cases based on their complexity. ${ }^{110}$ The Council for the Judiciary is accountable to the Minister of Justice and Security for processing an agreed upon number of cases per budget year. In the practice within the courts, the main weakness of this model has manifested itself. Already in the reform debates, the fear was expressed that the Lamicie model would stimulate calculated behavior with regard to procedural decisions. ${ }^{111}$ Experiences in the practice of the past 16

${ }^{107}$ R.M. Berendsen et al. (group Tegenlicht), 'Opinie: Geef de rechtspraak eigen begroting' (De Volkskrant, 26 March 2018)

${ }^{108}$ Art. 104(1)-(5) Judicial Organization Act.

${ }^{109}$ Art. 91(1)(d) and 91(1)(e) Judicial Organization Act.

${ }^{110}$ Art. 2-4 Decree on the Financing of the Judiciary.

${ }^{111}$ See supra, B.I.1.1. 
years demonstrate that this fear was warranted, in the sense that considerations on the available budget have become more prominent in decisions of judges, e.g. on the use of limited time for court hearings, and Management Boards, e.g. on the use of single- or three-judge panels. ${ }^{112}$ An incentive for this behavior among judges is not so much the system of promotion and dismissal, which can have only a minor impact on one's individual position. Indeed, the possibilities for promotion are limited to only a few functions (e.g. senior judge, court (vice-)president, transfer to a higher court) and require many years of experience. Disciplinary measures are currently limited to a reprimand or dismissal and application of the latter measure, which can only take place through a procedure led by the Prosecutor General at the Supreme Court, is very rare. ${ }^{113}$ Instead, calculated behavior seems to stem to a greater extent from the intrinsic desire of judges to create as much time as possible for the handling of cases in accordance with high standards of professionalism, if need be by "gaming the system" in order to secure for their court a larger share of the available budget. ${ }^{114}$

Further insights on the accountability of the Council for the Judiciary can be gained from an analysis of the system of supervision of its functioning. Indeed, the Council for the Judiciary does not have absolute autonomy regarding the administration of the judiciary. The Judicial Organization Act provides for a detailed system of supervision. Still, in the practice so far this system - in particular the competences of the executive branch of government has not played an important role. In the designed system, the Minister of Justice and Security holds the strongest constraining powers on the Council. The Minister can issue general directions to the Council on the performance of its duties aimed at the proper operation of the courts. The Council has a right to present its view on the intended general directions and can prevent these directions from being issued if they would infringe the "exception of independence", which holds that the Minister in exercising his legal powers "may not involve himself in the procedural aspects or substantive assessment of or the decision in a specific case or category of case". ${ }^{115}$ As another restriction on judicial selfgovernment, the Minister of Justice and Security can set aside a decision of the Council for the Judiciary by Royal Decree if this decision is "manifestly contrary to the law or prejudicial to the proper operation of the courts". ${ }^{116}$ The Council for the Judiciary has an obligation to provide the Minister of Justice and Security, at the Minister's request, with

\footnotetext{
${ }^{112}$ Robroek, supra note 81.

${ }^{113}$ Art. 116(4) and 117(4) Constitution and Chapter 6A Act on the Legal Position of Judicial Officers. A reform is underway to allow for more variety of disciplinary measures, including a cut in a judge's salary in case of insufficient performance.

${ }^{114}$ Robroek, supra note 81.

${ }^{115}$ Art. 93(1)-(4) and art. 109 Judicial Organization Act.

${ }^{116}$ Art. 106(1) Judicial Organization Act.
} 
the information required to perform his duties regarding the supervision of the Council. ${ }^{117}$ Weaker constraining powers are held by the Board of Delegates, which consists of representatives of the courts, the Central Appeals Tribunal and the Trade and Industry Appeals Tribunal. This Board of Delegates gives solicited or unsolicited advice to the Council for the Judiciary regarding the performance of the Council's tasks. The Council must provide the Board with requested information needed by the Board to perform its duties. $^{118}$

As this analysis makes clear, key challenges regarding the guarantee of judicial independence in the Netherlands concern the balancing of NPM values and rule-of-law values with regard to the judicial organization. A further increase of the workload of individual judges, related to budget cuts, could eventually undermine the guarantee of the independent administration of justice. In this regard, it is essential that a sphere of autonomy of individual judges is ensured in which they can realize the required standards of professional quality in judging. The current model of judicial self-government has put the Ministry of Justice and Security at a greater distance from the judiciary. In its place, however, the Council for the Judiciary has been given the difficult task of representing judges and meeting their professional needs, on the one hand, while being given the task to realize managerial policy goals based on a limited budget, on the other hand.

\section{Judicial Self-Government and Politics: Independence in the Balance of Powers}

An important conclusion based on the analysis in the previous section is that the functional independence of the Dutch judiciary and individual judges has - so far-not been affected negatively by the reforms of the judicial organization. Judges claim the autonomy needed to ensure that cases are decided based on sound procedures and without unlawful pressure on individual judges relating to organizational concerns. More generally, also the factual independence of the judiciary, as a prerequisite for the impartial administration of justice, $^{119}$ seems to be safeguarded in the Dutch legal system. Debates on factual independence and on impartiality are few. An analysis of selected relevant issues will clarify how the Dutch judiciary can be assessed in this regard and to what extent a relation to judicial self-government exists.

Historically, political threats to judicial independence in the Netherlands have been few. The period of German occupation of the Netherlands during World War II (1940-1945) is considered exceptional. During this period, the Jewish president of the Supreme Court was forced to step down and the retirement age for judges was lowered from 70 to 65 years of

\footnotetext{
${ }^{117}$ Art. 105 Judicial Organization Act.

${ }^{118}$ Art. 90(3) and 90(4) Judicial Organization Act.

${ }^{119}$ See Franken, supra note $78,28$.
} 
age, allowing the occupying force to appoint Nazi judges in key positions. ${ }^{120}$ In the rule-oflaw framework which has developed since 1945, judges generally are much less afraid to reach judgments which might not please the government. Many examples of "judicial courage" can be identified, recently inter alia the order to the State to enhance efforts to reduce greenhouse gas emissions in the "climate case" initiated by the Urgenda Foundation; ${ }^{121}$ the recognition of civil responsibility of the State to pay damages to relatives of 350 Muslim men who were taken away from the enclave Srebrenica-and murdered later-for the State's failure to protect these men under the UN Dutchbat mission in the former Yugoslavia; ${ }^{122}$ and the recognition of civil responsibility of the State to pay damages to Indonesian widows and orphans for unlawful killings by the Dutch military in Rawagedeh during the Indonesian war of independence. ${ }^{123}$ This professional attitude connects with the position of the judiciary in the balance of powers. Judicial independence from the other branches of government is safeguarded not only de iure but also de facto, providing a safe space for expressions of "judicial courage" in politically sensitive cases. Moreover, the conception of the judicial function itself has evolved and in it currently provides for a stronger role of the judiciary in the "public life" of the Dutch society. ${ }^{124}$ Indeed, over time the view on the judicial function has increasingly become that judges should have a role in the development of the law, for example when interpreting "open norms" in legislation, and that the judiciary should act as a check on the executive power through the exercise of judicial review in administrative cases. Against this background, judges feel able and are called upon to perform a role which goes much further than being a mere "mouthpiece of the law" which applies legal rules to individual cases. $^{125}$

In order to safeguard the impartial administration of justice, parties can request a judge to withdraw from their case or they can file for the recusal of a judge. The number of requests for recusal of judges has increased over the years, but remains limited. Most requests, which are decided by another judicial panel in the same court, are not granted. ${ }^{126}$

\footnotetext{
${ }^{120}$ G. Corstens, 'Bescherm onze rechters tegen de politiek' (NRC Handelsblad, 9 January 2018). See also C. JANSEN \& D. VENEMA, DE HOGE RAAD EN DE TWEEDE WERELDOORLOG (2012).

121 Urgenda Foundation v. State of the Netherlands, District Court of The Hague, 24 June 2015, ECLI:NL:RBDHA:2015:7196.

${ }^{122}$ Foundation Mothers of Srebrenica et al. v. State of the Netherlands, Court of Appeal of The Hague, 27 June 2017, ECLI:NL:GHDHA:2017:1761.

${ }^{123}$ Foundation Komite Utang Kehormatan Belanda et al. v. State of the Netherlands, District Court of The Hague, 14 September 2011, ECLI:NL:RBSGR:2011:BS8793.

${ }^{124}$ D. Luban, Settlements and the Erosion of the Public Realm 83 GEORGETOWN LAW JOURNAL 2619, 2632 (1995).

${ }^{125}$ Ch.-L. De Secondat Montesquieu, De L'ESPRit des lois (1973).

${ }^{126}$ W. VAN ROSSUM, J. TIGCHELAAR \& P. IPPEL, WRAKING BOTTOM-UP. EEN EMPIRISCH ONDERZOEK (2012).
} 
A few times, suspicions of judicial bias in specific cases have drawn attention from the media. A high-profile case was the Chipshol case about the development of land near Schiphol airport, in which Judge Hans Westenberg was accused of having unjustly favored one of the parties. This judge and a colleague, who both had been acquaintances of the party, were later prosecuted for perjury for denying their friendship. They were however both acquitted because of a lack of evidence. ${ }^{127}$

Some specific tensions in the safeguarding of judicial independence in institutional interactions can be identified in relation to the field of criminal law. In this field, the Minister of Justice and Security has the competence to give general directions to the Public Prosecutor's Service ${ }^{128}$ and he can order the prosecution in specific cases. ${ }^{129}$ In practice, the latter competence has however never been used. More significantly, a high degree of autonomy exists in the discretion granted to the Public Prosecutor's Service to choose which cases to prosecute (opportuniteitsbeginsel). This principle is generally accepted as serving the effectiveness and efficiency of the criminal justice system and is complemented by the right of individuals to demand the prosecution of an alleged criminal offence of which they have been the victim(s). ${ }^{130}$ More problematic in light of the rule-of-law principle is the competence granted to the Public Prosecutor's Service to hand down criminal sentences for minor offences (OM-afdoening). ${ }^{131}$ This procedure allows for an appeal to a district court. Still, legal scholars and lawyers have expressed criticism holding that the inherent barriers in this arrangement-i.e. the psychological barrier to continue the procedure, the practical barrier of extra costs-could endanger the effective protection of a defendant's right to a "fair trial" as protected by Art. 6 ECHR. ${ }^{132}$

As a notable area of concern, criticism was expressed some years ago, inter alia by first instance judges, on the approach of the Council of State in immigration and asylum cases. ${ }^{133}$ The Salah Sheekh judgment of the European Court of Human Rights confirmed that the very formal approach of the Dutch highest administrative court-consisting of a review ex tunc and based only on government reports, not on report of NGOs, on the situation in the asylum seeker's country of origin-violated the right to a fair trial. ${ }^{134}$

\footnotetext{
${ }^{127}$ ‘Oud-rechters Kalbfleisch and Westenberg vrijgesproken van meineed’ (AD, 23 November 2012).

${ }^{128}$ Art. 127 Judicial Organization Act.

${ }^{129}$ Art. 128 Judicial Organization Act.

${ }^{130}$ Art. 12 Code of Criminal Procedure (Wetboek van Strafvordering).

${ }^{131}$ Act on the Deciding of Cases by the Public Prosecutor's Office (Wet OM-afdoening).

${ }^{132}$ J.J. Crijns, Het wetsvoorstel OM-afdoening: een wolf in schaapskledij SANCTIES 225 (2004).

${ }^{133}$ K. GRoeneNDIJK, Een VeNIJNIG PROCES (2008).

${ }^{134}$ Salah Sheekh v. the Netherlands, Judgment of 11 January 2007, Appl. No. 1948/04.
} 
However, this criticism was not directly connected with the model of judicial selfgovernment, but rather with views on the scope of judicial discretion for reviewing administrative action.

Finally, there are a few examples of direct confrontations between the judiciary and political actors. A debate about the space for politicians to express public opinions about decisions of the courts arose after parliamentarians criticized the decision of the Court of Appeal in Arnhem to release Saban B., a defendant in a high-profile criminal case who then fled to Turkey. ${ }^{135}$ Some politicians used this incident to argue for legislative reform to allow the easier dismissal of judges who have erred in judgments in specific cases. Responses from academia emphasized the importance of safeguarding the functional independence of judges, which includes space to make mistakes. The alternative, where judges can be fired for decisions taken, would lead to political influence on the courts which is not commensurable with the principle of the rule of law. ${ }^{136}$

In two recent cases, judges and politics clashed again. This time, Member of Parliament Geert Wilders criticized the impartiality of the judges allocated to the criminal cases in which he has been involved. In the first case, which concerned the allegedly offensive film Fitna, Wilders successfully requested the recusal of the presiding judge based on expressed empathy for applicants present in the courtroom. He was later acquitted in this case. ${ }^{137}$ In the second case, the extreme right-wing politician was on trial for "hate speech" against the Moroccan community in the Netherlands, having promised his supporters "less Moroccans" during a political rally. ${ }^{138}$ The court management, eager to anticipate criticism on the impartiality of the judicial panel, had selected judges who did not hold membership of a political party and had issued a press release to highlight this choice. This strategy raised criticism from legal scholars, as political membership of judges is not prohibited and judges are expected to be able to distance themselves from their own political or other beliefs when judging cases. ${ }^{139}$ A further point of criticism raised by Wilders concerned comments made by one of the judges on the panel with regard to the previous trial against the politician. On this point, the judge considered that she could still handle the case impartially, taking her cues from the applicable criminal laws. The judge did not withdraw and a request for her recusal was unsuccessful. ${ }^{140}$ Wilders was found guilty of "hate

\footnotetext{
${ }^{135}$ A. Ellian, 'Politiek moet zich niet met rechters bemoeien' (NRC Handelsblad, 5 October 2009). See also P.M.

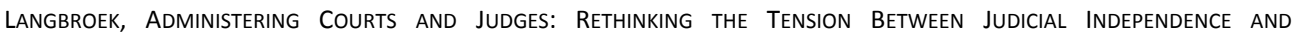
ACCOUNTABILITY (2009).

136 Ibid.

${ }^{137}$ District Court of Amsterdam, 23 June 2011, ECLI:NL:RBAMS:2011:BQ9001.

${ }^{138}$ District Court of The Hague, 9 December 2016, ECLI:NL:RBDHA:2016:15014.

${ }^{139}$ A. Korteweg, 'Politieke kleur van rechters speelt in Nederland geen rol' (Volkskrant, 13 March 2016).

${ }^{140}$ District Court of The Hague, 11 November 2016, ECLI:NL:RBDHA:2016:13520.
} 
speech" but the District Court was mindful of the special circumstances surrounding the trial of a politician-presumably the Court was thinking of media attention for the caseand did not impose a penalty. ${ }^{141}$ This case is currently on appeal, where Wilders requested the presiding judge to withdraw. He criticized her for left-wing political sympathy, allegedly demonstrated in the judge's chairpersonship of a committee which had awarded a master thesis prize to a student involved in the care for refugees. The judge did not grant this request, explaining that her very limited involvement with the student and her academic assessment of the master thesis could not cast doubt on her impartiality. ${ }^{142}$

Geert Wilders has also been critical of the judiciary in other ways, notably by challenging two appointments in the Supreme Court in 2011. The first time, this concerned Ybo Buruma, who was a professor of criminal law and had been actively involved in the elaboration of the Labor Party's political agenda. ${ }^{143}$ The parliamentary committee which advices the Minister about the appointment of Supreme Court justices, based on a short list established by the Supreme Court, ${ }^{144}$ ignored this criticism and gave a positive advice on the appointment of Buruma. The second time, Wilders was successful in obstructing the appointment of Diederik Aben as Advocate General at the Supreme Court. Aben had written a critical comment on the recusal of the judge in the first criminal trial of Wilders. For this reason, the politician framed Aben as "an apparently biased Advocate General [at the Court of Appeal of Amsterdam-EM] who in his spare time feels he has to defend his recused buddies". ${ }^{145}$ In this case, the parliamentary committee was persuaded to not go through with the appointment and the Supreme Court obliged in changing its short list of candidates. The reason provided by the parliamentary committee was that this second challenge of an appointment in the Supreme Court within a relatively short time frame could damage public confidence in the highest court. This decision met with criticism, pointing out that political interests had been given priority over the merit-based criteria for judicial appointments. ${ }^{146}$

In sum, there are neither structural threats to judicial independence in the Netherlands nor exemplary measures which have been taken against specific judges. Still, the rise of populism and the increased polarization in political debates has led to occasional

\footnotetext{
${ }^{141}$ District Court of The Hague, 9 December 2016, ECLI:NL:RBDHA:2016:15014.

142 'Reactie voorzitter gerechtshof op vraag Geert Wilders tijdens regiezitting' (press release, 26 October 2017, https://www.rechtspraak.nl).

143 G. Boogaard, 'De benoeming van Buruma' (blog Publiekrecht \& politiek, 10 March 2011, www.publiekrechtenpolitiek.nl).

${ }^{144}$ Art. $118(1)$ Constitution.

${ }^{145}$ F. Jensma, 'Hoe de PVV een raadsheer uit de Hoge Raad weerde' (NRC Handelsblad 17 December 2011).

146 Ibid.
} 
confrontations between the judiciary and politicians. This relatively stable position, honoring the rule-of-law principle, is underlined further by a mostly positive perception of the judiciary among the general public.

\section{Judicial Self-Government and the Society: Legitimacy, Transparency, and Public Confidence}

Already before the reforms of the judicial organization and since then too, the position of the Dutch judiciary in the society has generally managed to meet societal demands of legal, normative, and social legitimacy (1). Specific changes in judicial self-government can be classified as a response to the demand for transparency, which has become an increasingly important factor for securing public confidence in public institutions and connects with NPM values for organizational performance (2).

\section{Legal, Normative, and Social Legitimacy: A Sound Basis}

A brief reflection on the perceived legitimacy of the Dutch judiciary provides insight into the societal context in which the judiciary operates and, in this way, clarifies the background to the judicial system as it was established and has developed over time. Three dimensions of legitimacy can be identified. ${ }^{147}$ In the legal dimension, firstly, the appointment and functioning of judges in the Netherlands take place in accordance with the applicable constitutional and legal rules. As the previous analysis has demonstrated, interaction between the organizational framework and decision-making in concrete cases has intensified. ${ }^{148}$ The reform of judicial self-government has increased tensions in this regard. At the same time, this reform has prompted new initiatives from judges aimed at enhancing the quality of judicial decision-making for those seeking justice. For example, the National Consultation Bodies of judges (LOVs) have formulated guidelines to improve the guarantee of legal unity in specific types of cases. ${ }^{149}$

In the normative dimension of legitimacy, secondly, the organization and functioning of the Dutch judiciary can be assessed as mostly appropriate in connection with the principle of democracy and with moral values supported in the society. Not much public debate takes place on the quality of selection procedures and of appointed judges, the soundness of judgments, and the quality of procedures in terms of effectiveness and efficiency. ${ }^{150}$ Yet, debates occur regularly on specific topics of judicial decision-making, for example the ability of judges to properly assess non-legal aspects in their decision-making. Academic

\footnotetext{
${ }^{147}$ Kosar, supra note 4, 14-15.

${ }^{148}$ See supra, B.I.1.2.

${ }^{149}$ E.g. Sentencing Guidelines (Oriëntatiepunten straftoemeting) for criminal cases, https://www.rechtspraak.nl.

${ }^{150}$ See supra, B.
} 
scholarship has connected with these debates in research on inter alia the assessment of complex evidence (DNA, statistical analyses, psychiatric reports) in criminal cases ${ }^{151}$ and research on behavioral aspects of contract and tort law. ${ }^{152}$

In the social dimension, thirdly, the authority of the courts is for the most part accepted by different audiences, including political actors, judges, lawyers, academics, NGOs, and the general public. ${ }^{153}$ There is a high level of trust in the Dutch judiciary, which steadily ranks at around $70 \%$, higher than any other institution of government. In $2016,67 \%$ of the Dutch population had sufficient trust in the judiciary, of which $44 \%$ had much or very much trust. ${ }^{154}$ Furthermore, survey results on public confidence in the judiciary and other public institutions have demonstrated that the judiciary was the only institution for which a rise in public confidence occurred between 2008 and 2014 (see Figure 2, below, in which the trends for the judiciary and the lower chamber of Parliament are depicted). ${ }^{155}$

The reform of judicial self-government has not had a measurable effect on this level of public confidence. A likely reason for this is that citizens will not automatically connect their assessment of the authority of the courts-for example based on perceived procedural justice ${ }^{156}$ or the perceived independence of the judiciary from politics-to changes in the judicial organization.

Occasional drops in the level of public confidence in the judiciary have occurred in response to highly mediatized erroneous convictions in criminal cases, such as the Schiedammer Parkmoord case (2004) or the Lucia de Berk case (2009-2010). ${ }^{157}$ The evaluation of these cases led to the establishment of a Committee for the evaluation of closed criminal cases (Commissie evaluatie afgesloten strafzaken, CEAS, 2006-2012) and eventually to the competence of the Prosecutor General at the Supreme Court for a reassessment of closed criminal cases if this could be beneficial for the convicted person.

${ }^{151}$ E.g. W.A. Wagenaar, H. Israëls \& P.J. van Koppen, De slapende rechter (Amsterdam: Uitgeverij Bert Bakker 2009); T. Derksen, Lucia de B. Reconstructie van een gerechtelijke dwaling (Diemen: Veen Media 2006).

${ }^{152}$ W. van Boom \& I. Giesen (eds.), Civilology Book Series (The Hague: Boom Juridisch 2011-).

${ }^{153}$ Yet, a recent critical report claimed that access to justice is not sufficiently guaranteed for all citizens: M. Barendrecht, K. van Beek \& S. Muller, Menselijk en rechtvaardig. Is de rechtsstaat er voor de burger? (The Hague: HiiL 2017).

${ }^{154}$ The Netherlands Institute for Social Research (Sociaal en Cultureel Planbureau, SCP), Culturele Veranderingen (The Hague: SCP 2016), mentioned in SCP, De sociale staat van Nederland 2017 (The Hague: SCP), 292.

${ }^{155}$ The Netherlands Institute for Social Research (SCP), Continue Onderzoek Burgerperspectieven (The Hague: SCP 2016).

${ }^{156}$ K. van den Bos, Kijken naar het recht (Utrecht University 2014), http://njb.nl/kijken-naar-het-recht.

${ }^{157}$ C. Brants, 'Wrongful Convictions and Inquisitorial Process: The Case of the Netherlands' (2012) 80 University of Cincinnati Law Review 1069, 1090-1099. 
Figure 2: Public confidence in the judiciary and the lower chamber of Parliament

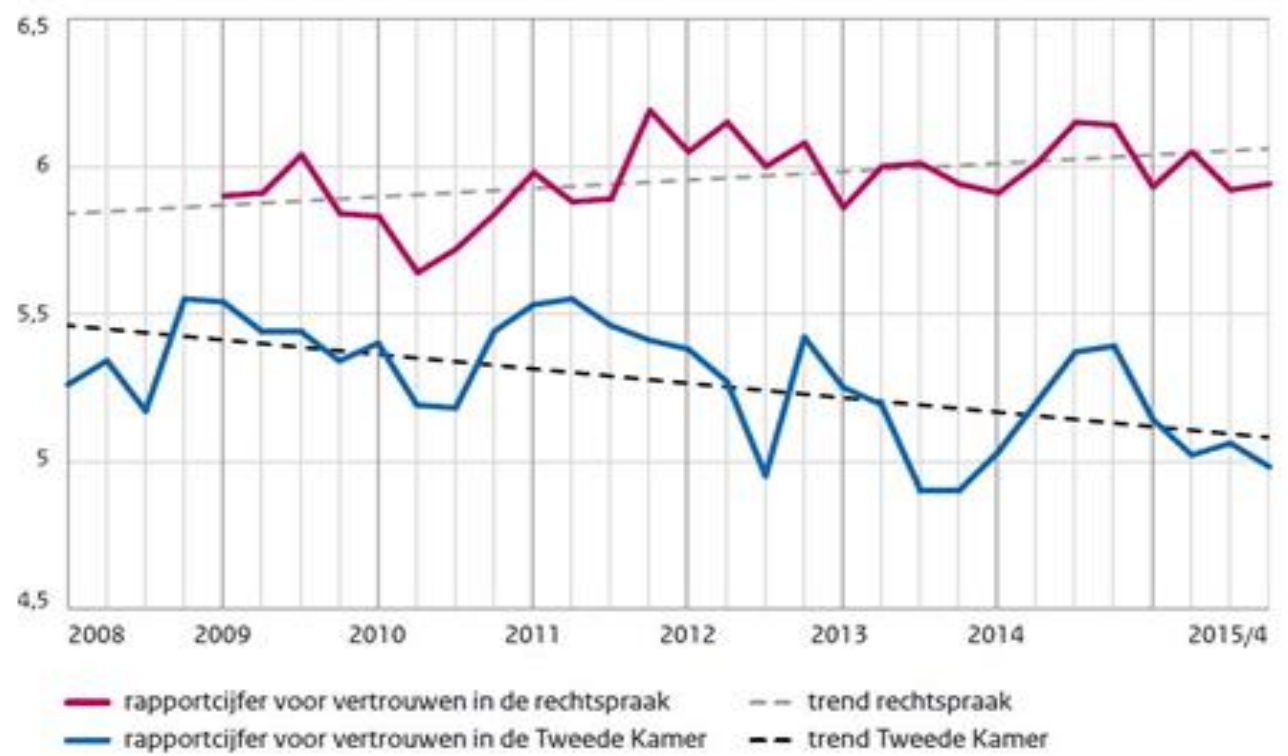

The lowest levels of trust in the legal system, including the judicial system, since the year 2000 occurred at the beginning of the new millennium (see Figure 3). ${ }^{158}$ It has been suggested that this decrease in public trust was related to the societal unrest surrounding the assassinations of right-wing politician Pim Fortuyn by an animal rights activist (2002) and film director Theo van Gogh by a Dutch-born Islamic extremist (2004). ${ }^{159}$

\footnotetext{
${ }^{158}$ Eurobarometer, http://ec.europa.eu.

159 ‘Hoeveel vertrouwen geniet de rechtspraak?’ (2016), https://www.rechtspraak.nl.
} 
Figure 3: Trust in the Dutch legal system (source: Eurobarometer)

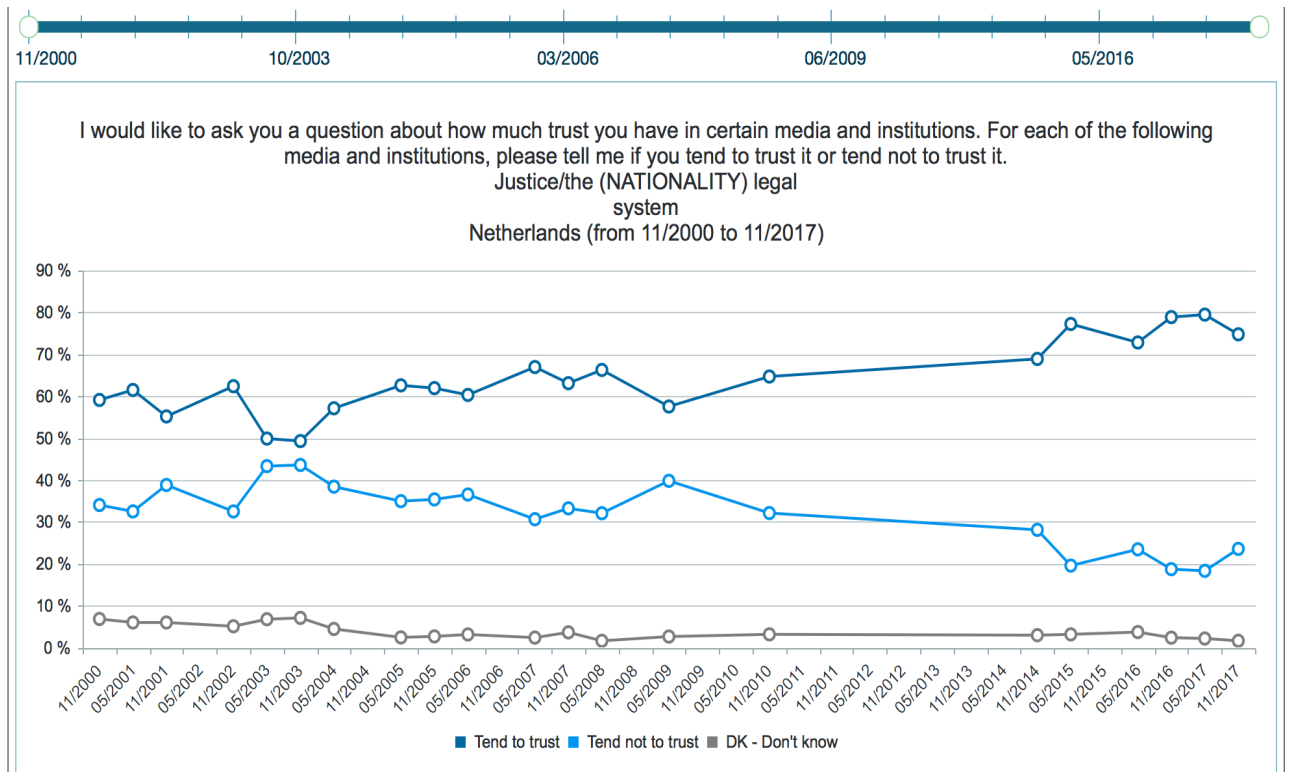

\section{Judicial Legitimacy in Context: The Contemporary Relevance of Transparency}

The reform of judicial self-government in the Netherlands paid notice to increased demands for transparency of public institutions, including the judiciary. These demands can be connected to the influence of NPM values, which include a client-oriented approach. Arguably, transparency in the handling of cases and in communication with citizens can also enhance the effectiveness and efficiency of the judiciary. ${ }^{160}$

The Council for the Judiciary is in charge of the National Service Centre for the Judiciary (LDCR), which handles the publishing of information and ICT services for the courts. Information about the judicial organization and its functioning has been made more available to the general public and users of the judicial system, primarily on the website of the judiciary. ${ }^{161}$ This website contains detailed information about judges, in particular a register of extra-judicial activities of judges, and a broad selection of anonymized judgments handed down by the courts. This website further contains information for the general public about the judicial system and about specific procedures as well as more specialized information for legal practitioners and academics, such as annual reports of the Council for the Judiciary and the Supreme Court, and public speeches held by the President

\footnotetext{
${ }^{160}$ D. BROEDERS ET AL., SPEELRUIMTE VOOR TRANSPARANTERE RECHTSPRAAK (2013).

${ }^{161}$ https://www.rechtspraak.nl.
} 
of the Supreme Court. The Council for the Judiciary annually publishes a report which presents key figures on the quality of the judicial system (including the numbers of complaints and requests for recusal of judges), production and finances, and personnel and organization (including absences because of illness). ${ }^{162}$

An ongoing operation concerns the further digitalization of court procedures in the framework of the Quality and Innovation Programme (KEI) under the auspices of the Council for the Judiciary. Although the aim is to create more accessible procedures for litigants and lawyers, the process of implementation of ICT solutions has not run very smoothly so far and has given new input for discussions on judicial autonomy within the organization. ${ }^{163}$ In April 2018, a consultation was started between the Council for the Judiciary and the Minister for Legal Protection (one of the current two Ministers of Justice and Security) with the aim of guaranteeing internal support within the judiciary for the process of digitalization and the aim of clarifying competences and responsibilities in the management structure for this process. ${ }^{164}$

The more hierarchical structure in judicial self-government, which connects with NPM values, manifests itself also in the current media policies for the judiciary. The chairperson of the Council for the Judiciary acts as the "face" of the judiciary in public debates which concern the judiciary as a whole, such as the current debate on the guarantee of the independent and impartial administration of justice in increasingly polarized societies. ${ }^{165}$ In each court, selected judges are trained to act as "press judges", who have the task to provide a clarification of judgments handed down in high-profile cases. Furthermore, guidelines are available to courts on how to deal with the media. ${ }^{166}$

Current debate concerns the use of social media by courts and judges. Courts have accounts on Twitter, but use these accounts as a means for presenting information, similar to a website, rather than as a means for establishing "dialogues" with citizens. About 60 judges have personal Twitter accounts, which are used inter alia to present short summaries of judgments ${ }^{167}$ or to highlight European activities of a judge. ${ }^{168}$ The Judges'

\footnotetext{
162 Ibid.

${ }^{163}$ Reiling, supra note 62.

164 'Digitale procedures Rechtspraak blijven gewoon in gebruik' (press release, 15 April 2018, https://www.rechtspraak.nl).

${ }^{165}$ See F. Bakker, 'Nieuwjaarstoespraak 2018’ (speech The Hague, 11 January 2018, https://www.rechtspraak.nl).

${ }^{166}$ See Press Guidelines 2013, https://www.rechtspraak.nl.

167 Judge Joyce Lie, @JudgeJoyce.

168 Judge Marc de Werd, @European Courts.
} 
Code advises judges to choose an attitude of restraint in public expressions, including the use of social media. ${ }^{169}$ Incidents have been few so far, but they underline that a mishap can occur and might lead to negative publicity for the judiciary. An example concerned a judge who commented critically on the awarding of a prize for "politician of the year" to parliamentarian Wilders. The District Court where this judge is active obliged her to close down her Twitter account because of concerns about judicial independence from politics which this tweet raised. ${ }^{170}$

In sum, the Dutch judiciary benefits from a sound basis of legitimacy and makes efforts at being responsive to changing societal demands. As one further point of attention, the diversity of the composition of the judiciary should be mentioned here. Studies conducted under the auspices of the Council for the Judiciary have tried to explain why ethnic minorities are not well represented within the judiciary. Yet, the courts have not been very successful so far in recruiting more judges from diverse backgrounds, despite the increased ethnic diversity among law graduates. ${ }^{171}$ By contrast, the representation of women in the judiciary has been successful. In the courts of first instance, more than 50 percent of the judges are female. Indeed, the concern of gender balance has led some courts to strive for the recruitment of more male judges. ${ }^{172}$ Still, the representation of women is still lagging behind with regard to management positions and positions at the highest courts. ${ }^{173}$

\section{Repercussions of Judicial Self-Government for the Principle of Separation of Powers and the Democratic Principle: Constitutionalizing Autonomy}

As a conclusion to this analysis of the effects of changes in judicial self-government in the Netherlands, we will consider which repercussions of these changes can be identified for the constitutional principles of separation of powers (I) and democracy (II). In particular, this analysis will address the extent to which the demarcation of autonomy of judges and JSG bodies has found a place in the constitutional framework for the judicial system.

\footnotetext{
${ }^{169}$ Judges' Code, para. 2.5.4. See also S. DIJKSTRA, De RECHTER ALS EVENWICHTSKUNSTENAAR (2016).

170 'Twitterende rechter krijgt reprimande voor “Knettergek"-tweet over Wilders' (NRC Handelsblad, 21 December 2016).

${ }^{171}$ L. Verheij, 'Etnische diversiteit in de Rechtspraak' (installation speech Court of Appeal of The Hague, 2 June 2016, https://www.rechtspraak.nl). See also S. VAN DER RAAD, OTHERING AND INCLUSION OF ETHNIC MINORITY Professionals: A Study on Ethnic Diversity Discourses, Practices ANd NARRATIVES IN THE Dutch Legal WorkPLACE (2015).

${ }^{172}$ L. van Wijk, 'Vrouwelijke rechters in de meerderheid: wat is daarvan het probleem?' (Trouw, 22 May 2014).

${ }^{173}$ https://www.rechtspraak.nl.
} 


\section{Separation of Powers}

In general, we can identify several significant changes in the separation of powers in the Dutch system since World War II. Firstly, the transfer of competences by the Dutch state to the European Union and the recognition of the autonomous supranational EU legal order have affected the domestic separation of powers. In particular, the role of the national courts as "decentralized EU law courts" has provided judges with the competence to review national legislation, including Acts of Parliament, for its conformity with EU law. ${ }^{174}$ Secondly, judicial review of the conformity of parliamentary acts with fundamental rights has been achieved through the judicial use of the ECHR as a reference norm. In this way, the traditional prohibition of judicial constitutional review ${ }^{175}$ has become less significant. In combination with the first change, the relationship between the branches of government has shifted from the primacy of the legislator to a more balanced dialogue between the legislative and judicial branches. ${ }^{176}$ Thirdly, a change has come about through the reform of the system of administrative justice, including the integration of administrative jurisdiction in the courts of first instance and the stricter separation of legislative advice and judicial tasks in the Council of State. In this way, a more independent system of judicial review of administrative action has been established. ${ }^{177}$

The reform of judicial self-government was significant for the separation of powers too. First of all, the new architecture of the judicial organization reflects contemporary views, in which the judiciary operates in a relationship of "checks and balances" rather than a strict separation of functions with the legislative and executive branches of government. Judicial self-government fits well with this shift in the balance of powers when compared to the traditional government by the executive branch. ${ }^{178}$ Secondly, the reform of judicial selfgovernment has prompted new reflections on the separation of powers, in particular by putting more emphasis on the guarantee of functional independence of judges involved in the management for the courts. In this regard, critical analyses have claimed that the Council for the Judiciary resembles a body of the executive power, notwithstanding the Parliament's explicit classification of the Council as a body of the judicial branch. ${ }^{179}$ Advanced arguments focus on the Council's composition of members appointed by the

\footnotetext{
${ }^{174}$ M. Claes, The National Courts' Mandate in the European Constitution (2006).

${ }^{175}$ Art. 120 Constitution.

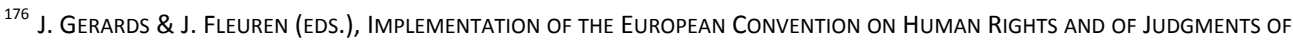
THE ECTHR IN NATIONAL CASE LAW (2014).

${ }^{177}$ See supra, A.II and B.II.

${ }^{178}$ Martens \& Ten Kate, supra note 3, 1615.

${ }^{179}$ Kamerstukken II, 1999/2000, 27 182, no. 3, 3; Kamerstukken II, 2000/2001, 27 182, no. 6, 10.
} 
Minister of Justice and Security for a limited term of office. ${ }^{180}$ This classification is particularly problematic when criticism from judges is taken into account, holding that the Council has a tendency to coordinate its actions more with the Minister of Justice and Security than with the courts. ${ }^{181}$ This potential blurring of the separation of institutions goes hand in hand with an increased "gray area" surrounding the separation of functions. In particular, the competence awarded to the Council for the Judiciary to issue guidelines to the courts empowers it to act as a quasi-legislature. In terms of managerial thinking, this shift in the distribution of functions could however also be considered to function as a useful "irritant" in the judicial organization, urging judges themselves to initiate activities aimed at the more effective and efficient administration of justice. An example is the initiative of the National Consultation Bodies (LOVs) to "take back control" over court procedures through the design of professional standards for judges. ${ }^{182}$ Finally, the managerial turn has had positive effects on transparency of judges with regard to their extra-curricular activities, in this way ensuring that the separation of powers is guaranteed at the micro level of individual judges too. ${ }^{183}$

\section{Democratic Principle}

The reform of judicial self-government has not had major effects on the understanding of the democratic principle in the Dutch system. A potential concern remains that co-option is a strong mechanism in the selection and appointment of judges. The adequate functioning of this mechanism requires a high degree of professional integrity among judges in order to prevent nepotism. At the same time, this power of co-option is counterbalanced by the power of the executive power to formally decide on the appointment of judges. Yet, this structure remains inherently vulnerable, since it does not fully exclude political influences on the appointment of judges. ${ }^{184}$ As it is, the strong rule-of-law culture among actors in the Dutch system safeguards that the democratic principle, underlying the competence of the executive power, and the principle of independence, underlying the judiciary's competence, keep each other in balance.

Besides this dance between public institutions, the increased societal call for responsive government has prompted initiatives to enhance participation of citizens in regulatory procedures as well as in court cases. In the judicial context, a democracy-enhancing

\footnotetext{
${ }^{180}$ P. Bovend'Eert, Wat is er mis met de rechterlijke organisatie? ARS AEQUI 406, 409 (2016).

${ }^{181}$ See supra, B.I.1.2.

${ }^{182}$ See supra, A.I.

${ }^{183}$ See supra, B.III.2.

${ }^{184}$ Compare the controversies surrounding two intended appointments in the Supreme Court in 2011; see supra, B.II. See also P.P.T. Bovend'Eert \& C.A.J.M. Kortmann, Het Court-Packing Plan van het cabinet-Kok NEDERLANDS JURISTENBLAD 1769, 1771 (2000).
} 
measure which deservers mentioning has been the introduction of the right of victims and relative of victims to speak in court during the trial in criminal cases. ${ }^{185}$

\section{Conclusion}

This article started out from the observation that judicial government in the Netherlands has changed drastically since the 1990s, prompted by a call for "organizational emancipation" of the judiciary in the balance of powers and implementation of insights from New Public Management theories to improve judicial performance. In the analysis of this development, it has become clear how rule-of-law values and NPM values interact in the contemporary legal framework for the Dutch judiciary. A predominant challenge in the shaping of a judicial organization based on these two sets of values concerns the demarcation of spheres of autonomy for the involved actors: judges, bodies for judicial self-government (most importantly the Management Boards at the courts and the Council for the Judiciary) and the Ministry of Justice and Security. The analysis in this article has mapped choices made in the architecture for the judicial organization as well as the experiences with this new model in practice.

As a conclusion to this analysis, judicial self-government in the Netherlands can be assessed as functioning adequately on the basis of a combination of rule-of-law values and NPM values. Judicial independence remains a core constitutional value. Factors that influence the de facto independence of the Dutch judiciary concern the integrity of individual judges and the systemic guarantees that enable judges to decide cases free from external pressure. The establishment of a stronger structure for self-government, in particular the concentration of competences with the Council for the Judiciary, has led to fierce debates within the judiciary concerning these systemic guarantees. On the one hand, a change in the organizational culture at the service of an effective and efficient judicial system (e.g. through more uniform procedures and through specialization of judges) seems unavoidable to meet contemporary societal demands within the constraints of a limited budget. On the other hand, organizational pressures should not prevent judges from exercising their individual capacity for judgment in each case that comes before them. It will remain a challenge for those involved in judicial government to do justice to both of these requirements.

The Dutch judicial organization, it can be concluded, is largely dependent on traditions of checks and balances between the judiciary and the executive branch which have developed over time. In this regard, a next change in judicial self-government could be on the horizon. Indeed, increased political pressure on judiciaries in other EU member states, such as Hungary and Poland, has inspired new reflections and has started to yield calls for stronger de iure safeguards for the Dutch judiciary against political control. In the words of

${ }^{185}$ Art. 51e, 258, and 260 Code of Criminal Procedure. 
the former President of the Supreme Court, Geert Corstens: "Of course, there are all sorts of informal safeguards, but exactly these fall over easily when other winds start blowing." ${ }^{186}$

${ }^{186}$ Corstens, supra note 120. 